\title{
The Biology of Balanus balanoides. I. Growth rate and its relation to Size, Season and Tidal Level.
}

\author{
By \\ Hilary B. Moore, Ph.D., \\ Zoologist at the Marine Biological Station, Port Erin, Isle of Man.
}

With 4 Figures in the Text.

THREE workers have contributed recently to our knowledge of the growth rate of Balanus balanoides : Runnström (1925), and Hatton and FischerPiette (1932). The former kept a single patch of barnacles under observation for a year at Herdla, which is about $27 \mathrm{~km}$. north-west of Bergen. By estimating at different times of year the size distribution of the spat, and of the first and second year groups, which he could differentiate by their size, colour and shape, he obtained a curve for the growth of the animal for the normal duration of its life. His investigations also cover the maturation of the gonads. And he finds that the normal course of life is for the animals to settle on the rocks in April. Towards the end of the following year the ovaries are developed, and in the spring of the third year the larvæ are liberated. Most of the adults die after this, only a possible few surviving to spawn the following spring. His measurements comprise the length only of the shells, and he says that the successive year groups may be distinguished by their degree of flattening.

Hatton and Fischer-Piette (1932) worked on the growth of individuals near St. Malo during the greater part of two years, and investigated the effects of varying degrees of shelter and tidal level on this growth rate. Their results will be referred to in greater detail later in this paper, but they may be summarised in the following two relations: the most larvæ settle, and the greatest growth takes place, at the most exposed places, and at the lowest tidal levels. They show also that growth is at a maximum from April to June-July, and practically at a standstill for the rest of the year.

\section{Methods.}

In the present work it was felt that it would be desirable to employ a method of measurement which would allow of the calculation of the volume of the animal. This is necessary in the first place to cope with the variations of shape as between individuals, and in the second place to afford a measure which, unlike length, increases more or less in a simple 
ratio with age. Such a measure is more than ever necessary when, as Runnström states, the animal is continuously changing its conicity throughout life (although no such change has been detected at Port Erin). In the present paper, where the volume of the animal is referred to, this is the volume of a cone with a height equal to the height of the apex of the shell above the surface of attachment, and a basal diameter equal to the average of the length and breadth of the base. Such an assumption takes no account of the truncation of the cone, but it gives a value related sufficiently closely for our purposes to the external volume of the animal, and it is the only such value which may readily be obtained from measurements of the animal taken in situ on the rocks. It is hoped in a future paper, to relate this calculated volume to the true body weight of the barnacle. Where the length of the animal is given, this is the length of the base through the rostrum and carina, as in the two works referred to above.

The locality chosen was a vertical face of rock, facing south-west, in a long cleft in the rocks running from low to high-water in the Dub Reef in Port Erin Bay. The position is fairly exposed, with few fucoids growing on the rocks. Three patches of barnacles were selected on this surface, one near the bottom of the barnacles zone (B. 1), one higher up (B. 2), and a third (B. 3) at the extreme top of their range. By inspection these patches seemed quite typical for this region. Their levels, at the midheight of the patches, are as follows : $\dagger$

B. $1 . \quad-0 \cdot 75$ feet 0. . or about mid-tide level.

B. $2 .+2 \cdot 74$ feet $0 . \mathrm{D}$.

B. 3 . +4.58 feet o.D., or about high water of neap tides.

Full scale photographs allowed of the identification of individuals, about a hundred of which were kept under observation on each patch for a whole year. At intervals of from one to two months each individual was measured (length, breadth and height), and as soon as the new spat were large enough for measurements in the field, a series of these also was included. A note was made also of all individuals which died, and whose shells were either empty or missing.

As the newly settled spat were too small for measurement in situ, a number of these were distinguished by a ring marked round them on the rock, and a series of them was brought in from time to time for accurate measurement in the laboratory. When the barnacles are small, it is possible to detach them from the rocks without damage. Two sets of these small barnacles were collected, the first group " $\mathrm{O}$ " representing typical animals which had settled about the end of April, while the second

$\uparrow$ Levels determined by Mr. J. R. Bruce. The tidal range at Port Erin is about \pm 4 feet for average neap tides, and \pm 8 feet for average spring tides. 
group "Q" represent spat which settled later in the year, and whose growth was apparently retarded at first by the summer heat. Finally the length of about eight hundred barnacles in each of the groups B. 1, B. 2 and B. 3 was measured in June 1932, and from these a size-distribution diagram was obtained for each group for the date in question.

\section{Treatment of Results.}

The individual measurements for each patch, about five thousand in all, are too numerous to reproduce here, but their analysis is given in Tables I, II and III. For each patch of barnacles there is a series of read. ings from which the volumes can be calculated as described above, for each of about a hundred individuals, and taken at five to seven times in the year. Each of these periods has been dealt with separately, and in it the individuals have been grouped according to their size at the commencement of the period, the limits of each group having been so chosen as to include an adequate sample. The limits of experimental error in the initial measurements are of the order of about $\pm 10 \%$. This is reduced in the grouping together of a number of animals, but since the groups vary in size, no final error can be given which would be universally applicable. In each of the groups, as shown in the tables, the stated volumes and volume increments are the means of all the individuals comprised in the group. From the increase in volume in each group the growth rate has been calculated, this being defined as the average percentage increase in volume per ten days.

\section{Relation of Growth Rate to Size.}

The figures show very marked differences in the growth rates of the barnacles, both at different sizes and at different times of the year, as well as at different levels. Comparison of the last two factors is rendered difficult by the very much greater growth rates of the smaller individuals. In Figure 1 (and Table IV), seasonal variation has been eliminated, by plotting the year's mean growth rate against size and shows the difference of growth rate with size, as well as the fact that the barnacles are growing faster at successively higher levels.

\section{Seasonal Variation in Growth Rate.}

The seasonal variation in growth rate may be seen from the figures in the last columns of Tables I, II and III by interpolating values to allow of the comparison of animals of the same size. The simplest condition, found in the smaller animals of all the patches, is that of an animal having 
a high growth rate for a short period in the spring or summer, followed by a period of slower growth throughout the winter. The time of maximum growth rate varies on the different patches, and with different sizes of barnacles, but sufficient information is not yet available to allow of an interpretation of these differences. It is to be hoped that they may become clearer when more is known about the seasonal changes in the

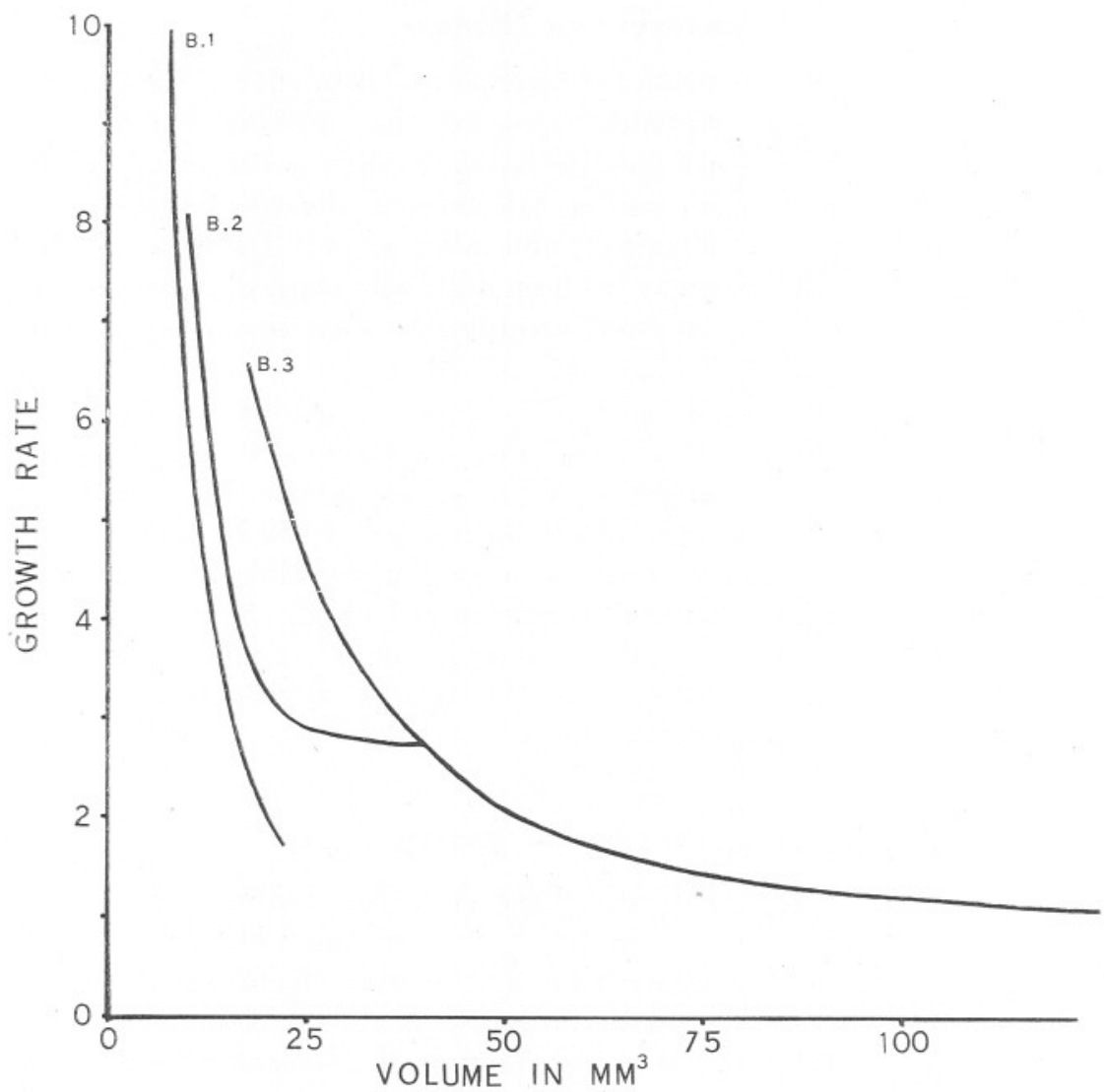

Fig. 1.-Relation of mean yearly growth rate to size. The rate is greatest in the smallest individuals, and in those at the highest level (B. 3).

soft parts of the barnacle. In the larger individuals of B. 1 and B. 3, there is, in addition to the summer growth period, a second period of increased growth rate in the winter, which in the largest members of B. 3 considerably surpasses the summer rate. The fact that such a winter period is not shown in B. 2 may possibly be due to the overwide spacing of the winter readings. 
The Growth of the Newly-settled Spat.

All the data discussed up to this point, concern barnacles which were sufficiently large to be measured in situ on the rocks. It is necessary to consider here the growth curves obtained for the spat of the " $\mathrm{O}$ " and "Q" groups, samples of which were periodically brought into the laboratory for measurement. The measurements of these are given in Table $V$, and the results are shown graphically in Figure 2.

On April 25th, 1931, large numbers of Cypris larvæ commenced to settle on the rocks, and a first sample of metamorphosed individuals was

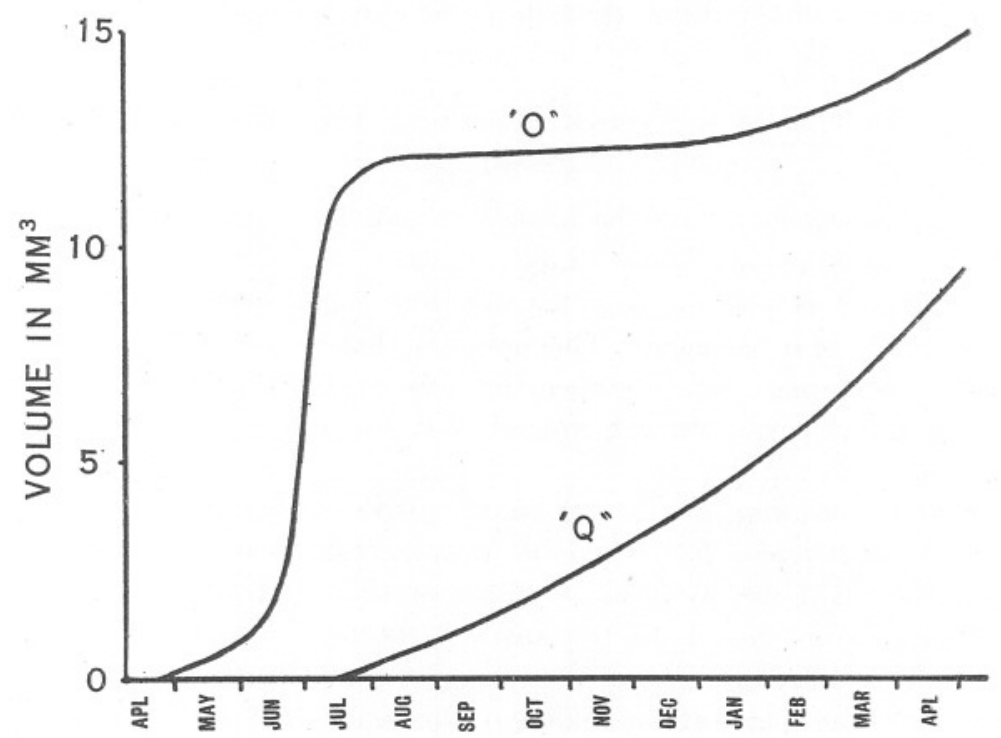

FIG. 2.-Growth of young individuals during their first year. The " $O$ " group are typical, and the "Q" group late-settled specimens.

collected on April 30th. The individuals marked at this time comprise the " $\mathrm{O}$ " group, and represent the typical members of the community. Later in the year a number of very small individuals were noticed, whose size suggested that they were newly settled. On October 5th these had a volume of $1.75 \mathrm{cu}$. $\mathrm{mm}$. as compared with an average volume for the " $\mathrm{O}$ ' group of $12 \mathrm{cu} . \mathrm{mm}$. A number of these smal individuals were ringed, and they comprise the "Q" group. The suggestion that these were newly settled spat was however disproved by a photograph of the rock surface taken on July 22nd in which some of the "Q" group were seen to be already present. It would appear, therefore, that these " $\mathrm{Q}$ " barnacles settled later than the " $\mathrm{O}$ " ones, and were not able to get through their early period of rapid growth before the heat of the summer. 
Figure 2 shows the retarding effect of the summer hot period on the barnacles of both groups. By the beginning of the following year, the " Q " group have made good progress, and are catching up with the " $\mathrm{O}$ " group, so that in May their respective volumes are $9 \cdot 6$ and $14.9 \mathrm{cu} . \mathrm{mm}$. One point which emerges from the comparison of these two groups is that the wide differences of size found in first-year barnacles is not maintained in the second year, thus justifying the choosing of a definite size as representing the typical barnacle of any age, as is done below. As the barnacles of the " $\mathrm{O}$ " and " $\mathrm{Q}$ " groups were not taken from the exact level of any of the three patches, their results have not been utilised in the calculation of the initial portion of the curves shown in Figure 3.

\section{The Growth of a Typical Barnacle through Successive YEARS.}

The measurements have been carried out for one year only, but, since they cover the whole range of sizes of individuals found in the locality, it is possible to construct from them a curve representing the whole life of a barnacle. This assumes that the year of observation was a typical one. The temperature observations in Port Erin Bay throughout the period do not suggest that the year 1931-32 was very abnormal.

The first measurement, in situ on the rocks, of the young barnacles was made in August 1931 when the average first-year members of the groups B. 1, B. 2 and B. 3 had volumes of $4 \cdot 66,8 \cdot 84$ and $6 \cdot 38 \mathrm{cu} . \mathrm{mm}$. These figures are based on too small a number of individuals to be accurately representative, but they suggest that the greatest growth of young spat takes place at the middle of the zone (B. 2), and then successively less well at the top of the zone (B. 3) and at the bottom of it (B. 1).

Commencing with the above sizes, and using growth rates for each period, which were read from curves relating growth rate to initial size, the growth of a typical barnacle for each patch was calculated for a series of years. The figures so obtained are given in Tables VI, VII and VIII, and the results are shown graphically in Figure 3. The calculations have been continued in the case of B. 1 and B. 2 into their third year, and in the case of B. 3 into its fourth year. As will be shown later this represents the span of life of the majority of the individuals of B. 1 and B. 2, but a portion only of the life of many individuals of B. 3 .

It will be seen from Figure 3 that, with the exception of the first year, the growth rate is greatest on B. 3 and slightly less on B. 2. The deficiency in the first year is regained by B. 3 by the beginning of the second year, and from then on members of B. 3 are always slightly larger than 
members of B. 2 of the same age. Throughout the whole of its life B. 1 has a much smaller growth rate than either of the other patches.

Runnström's data give a length at the end of the first year (Dec.-Jan.) of about $6.5 \mathrm{~mm}$., and for a similar period in their second year of about $9.5 \mathrm{~mm}$. Hatton and Fischer-Piette's figures for the same ages are between 2.5 and $3.0 \mathrm{~mm}$. for the first year, and about $5.5 \mathrm{~mm}$. for the second year. They do not give sufficient data to allow of the conversion of these data into volumes, but if the Port Erin figures are expressed as length, the results are as follows :-

\begin{tabular}{|c|c|c|c|c|c|}
\hline Lengt & HERDLA. & B. 1 & $\begin{array}{r}\text { PORT } \\
\text { B. } 2\end{array}$ & $\begin{array}{l}\text { ERIN. } \\
\text { B. } 3\end{array}$ & ST. MALO. \\
\hline $\begin{array}{l}\text { the first year } \\
\text { ength at the end of }\end{array}$ & $6.5 \mathrm{~mm}$. & $4 \cdot 7$ & $5 \cdot 3$ & $5 \cdot 2 \mathrm{~mm}$. & $2 \cdot 5-3.0 \mathrm{~mm}$ \\
\hline ear . & $9 \cdot 5 \mathrm{~mm}$. & $6 \cdot 5$ & $7 \cdot 6$ & $8 \cdot 1 \mathrm{~mm}$. & $5.5 \mathrm{~mm}$. \\
\hline
\end{tabular}

Thus in all cases the values for Port Erin lie between those of Runnström and those of Hatton and Fischer-Piette. The former does not state the level in his locality, or its condition with regard to exposure. In the case of Hatton and Fischer-Piette's figures there is a considerable difference at the end of the first year in the sizes attained in sheltered and in exposed positions; but this difference appears from their graph to have been entirely made up in the second year, although they do not mention the fact in the text.

The sequence of growth rates in these three localities is of interest since it is that of ascending latitude, the growth rate being highest in the most northerly latitudes. (St. Malo $49^{\circ}$ N., Port Erin $54^{\circ}$ N. and Herdla $60^{\circ} \mathrm{N}$.)

\section{LENGTH OF LifE.}

According to Runnström, most of the barnacles die after spawning, in their third year, only a possible few living to spawn again the following year. The data to be considered below show that, while this is true for the lowest zone (B. 1), and to a lesser extent for B. 2, the members of B. 3 may live for five or six years, and probably considerably longer.

It is a general observation on most parts of the coast which are not very exposed, that barnacles are smaller near low water, and become steadily larger towards high water: and further that at the extreme top of their range, there are found individuals much larger than are found anywhere lower down. In order to obtain an expression of these differences, between 700 and 1000 individuals were measured on each of the three patches, in June 1932. Owing to the large number of measurements required, lengths only, and not volumes were taken, but volumes were obtained by formula from the lengths, as will be explained later. It must be emphasised that the object of this set of readings was to obtain a measure 
of the frequency of occurrence of the larger members of the community, and not to obtain the year group sizes. Thus, owing to the large size of the groups taken, the exact position of the size group peaks is somewhat masked in Figure 4.

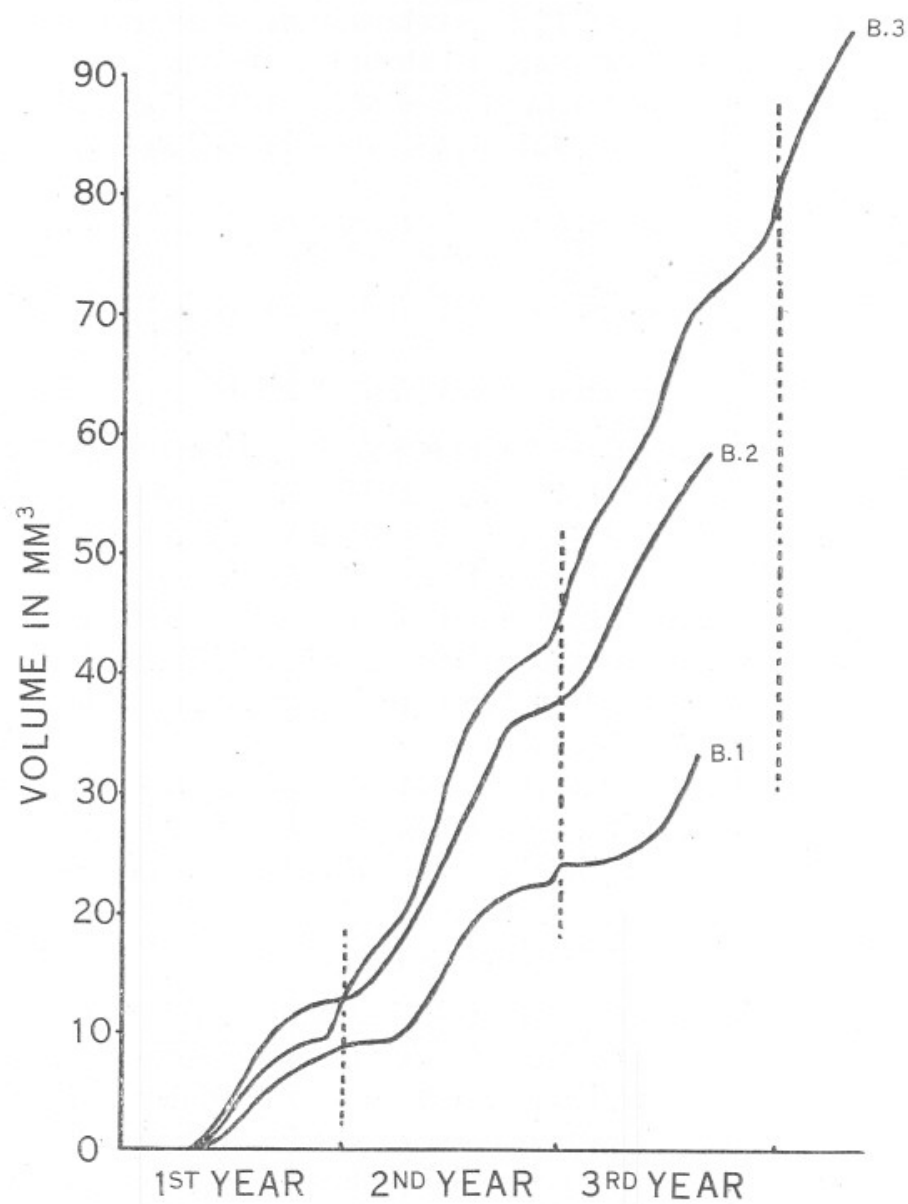

FIG. 3.-Growth throughout the life of typical individuals at the three levels. The curves for B. 1 and B. 2 represent the normal duration of life at those levels, but B. 3 individuals may live for perhaps six or more years.

The lengths were measured, as in Runnström's work, through the rostrum and carina. The percentages in each millimetre groupneglecting the spat-which were too small to be measured accuratelyare given in Table IX. The spat were counted, and their numbers are entered in Table IX, but these have not been taken into account in the calculation of the percentages. 
In Figure 4 these percentages have been plotted against lengths. It must be remembered, in examining this graph, that while volume is approximately a straight line function of age, length is not so. A curve has therefore been superimposed in Figure 4 relating volume to length for the barnacles in question. This has been drawn from the formula

$$
\text { length }=\sqrt[3]{\frac{\text { volume }}{0 \cdot 084}}
$$

which has been arrived at by taking the mean value of $\frac{\sqrt[3]{\text { volume }}}{\text { length }}$ for various sizes, in all individuals measured during the year. Runnström stated that there was a change of apical angle of the older barnacles.

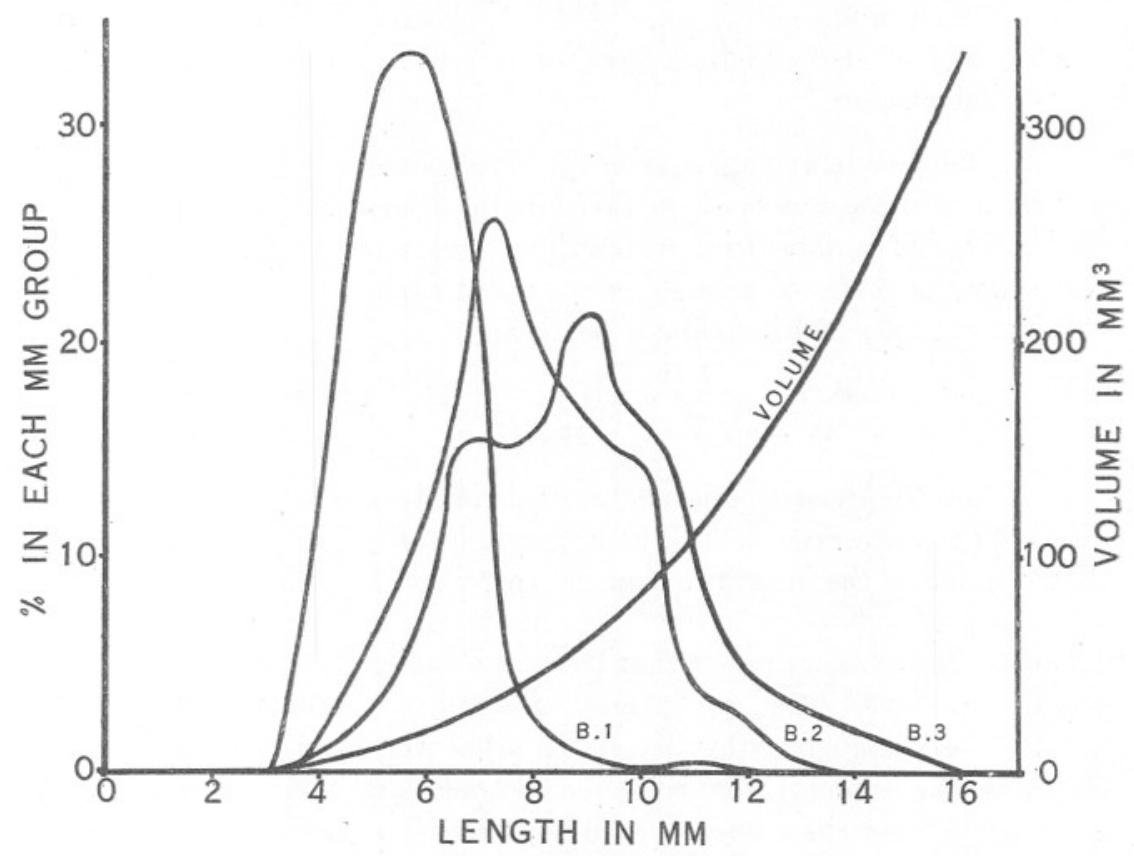

FIG. 4.- Size distribution curves for the three patches, and a curve relating to length volume.

Our groups do not show any trace of such a change, although it has been noted on other parts of the Manx coast, especially where there is much overcrowding; and also elsewhere in isolated specimens growing under estuarine conditions. Since in our group there is no change of shape, and the volume is a straight line function of the cube of the length, such a formula may legitimately be used to interpret the lengths of Figure 4 as volumes.

Although not produced for this purpose, Figure 4 indicates the sizes of 
the various year groups on the three levels in June, and these values bear out the validity of those which have been obtained by the other methods already described. B. 1 shows a second year peak only, B. 2 a second and a doubtful fourth year peak only, and B. 3 second and third year peaks. The three curves show clearly the size differences at the three levels, especially if the lengths are translated into volumes from the curve included in the figure for that purpose. Summarising these results we get the following :-

$4 \%$ of B. $1,58 \%$ of B. $2,72 \%$ of B. 3 have a volume greater than $50 \mathrm{cu} . \mathrm{mm}$.

$0 \cdot 3 \%$ of B. $1,18 \cdot 5 \%$ of B. $2,33 \cdot 0 \%$ of B. 3 have a volume greater than $100 \mathrm{cu} . \mathrm{mm}$.

$0 \cdot 0 \%$ of B. $1,0 \cdot 0 \%$ of B. $2,6 \cdot 0 \%$ of B. 3 have a volume greater than $200 \mathrm{cu} . \mathrm{mm}$.

The difference in average age on the three patches is further borne out by the death-rate observed on them in the course of the observations. The number of animals from which these figures are drawn, is small, but their differences are too great to be the result of chance.

Death-rate per 100 individuals per year.
B. 1
B. 2
B. 3
35
21
3

The above figures concern only animals of about four months old and over. The death-rate on B. 3 is surprisingly low, and it may be noted that not one of the deaths in that group occurred among the very large specimens.

It has already been noted that there is a relatively sparse population in the top, B. 3 , zone, and also that small individuals are relatively slightly less common at that level. In other words, on the top zone the young barnacles find it hard to gain a foothold, and to attain a sufficient size to withstand the adverse conditions there, but having once attained a sufficient size, they are likely to grow faster and to live longer than they would have done at a lower level where their earlier life would have been easier.

Hatton and Fischer-Piette's work shows clearly the greater numbers of young Balanus settling at lower levels, but the meaning of their mortality figures is less clear. At their most exposed locality the mortality at the end of the first year, is considerably less at low water than higher up the shore. On the other hand, in a more sheltered locality, the mortality for the first year becomes steadily greater towards low water. Unfortunately they give no figures for the mortality on the highest patch of all, at the top limit of the Balanus zone. 


\section{General.}

The difference of level of the three groups of Balanus studied is not very great. It covers, however, the whole range for the shore at Port Erin. B. 1 was typical of all those barnacles growing at that and a lower level on the beach, that is to say, on this beach, down to about three feet below mean sea level. B. 2 was typical of the intermediate zone, and B. 3 of the small uppermost zone. The latter is the upper limit of their distribution, and although a few may be found slightly higher, none extend more than two feet higher, that is to say above 7.5 feet above mean sea level.

The B. 1 type of barnacles are small, and usually rather less numerous than the B. 2 type. The latter are undoubtedly the most numerous on the shore, and hence may be taken as typical. The B. 3 type, although less numerous than B. 2, is usually much larger. It almost certainly spawns many times in its life, and, being large, produces a large amount of spawn. The B. 2 type, on the other hand, usually spawns only once and then dies. (Runnström, 1925, p. 39.) It is therefore possible that the B. 3 type plays a much more significant part on the shore than its numbers would suggest. It is hoped in a later paper to extend this account to less, and more exposed localities.

I should like to express my indebtedness to Mr. J. R. Bruce for assistance in making some of the measurements, and to all members of the staff here who have assisted at various times; also to Prof. J. H. Orton and Dr. E. J. Allen for helpful criticism of the paper.

\section{SUMMARY.}

1. The volumes of Balanus balanoides, at three levels of the shore, have been observed for a year.

2 . The young barnacles grow very much faster than older ones.

3. The growth rate varies greatly with age, season and tidal level, but in general there is a period of maximum growth in the summer, and very little growth in the winter.

4. Growth, except during the first year, is greatest higher up the shore.

5. Young barnacles, which settle too late in the year, have their growth retarded by the summer heat, but almost catch up in size the earlier settled spat, by the beginning of the next year.

6 . The growth rates found are intermediate between those recorded from Herdla (near'Bergen), and those from near St. Malo.

7. Most of the lower- and middle-zone barnacles die in their third year, but those from the extreme top zone may live for five years or more. 


\section{REFERENCES.}

Hatton, H., and Fischer-Piette, E. 1932. Observations et Expériences sur le Peuplement des Côtes Rocheuses par les Cirripèdes. Bull. de l'Inst. Océan. Monaco. No. 592.

Runnström, S. 1925. Zur Biologie und Entwicklung von Balanus balanoides (Linné). Bergens Museums Aarbok. Naturv. Raekke. 1924-1925. 1 Hefte Nr. 5. 


\section{TABLE I.}

The Growth Rates on the B. 1 Patch throughout the Year.

Volumes in cubic millimetres. Growth rate is the percentage increase in volume per ten days.

\begin{tabular}{|c|c|c|c|c|c|c|}
\hline \multirow[b]{2}{*}{1931} & Date. & $\begin{array}{l}\text { Initial } \\
\text { volume } \\
\text { range. }\end{array}$ & $\begin{array}{c}\text { Initial } \\
\text { volume } \\
\text { average. }\end{array}$ & $\begin{array}{c}\text { Final } \\
\text { volume } \\
\text { average. } \\
0.34\end{array}$ & $\begin{array}{l}\text { Mean } \\
\text { volume } \\
\text { for the } \\
\text { period. }\end{array}$ & $\begin{array}{c}\text { Growth } \\
\text { rate. } \\
26.9\end{array}$ \\
\hline & $\begin{array}{l}5 \text { May } \\
\text { to } \\
\text { 20 June }\end{array}$ & $\begin{array}{c}0-6 \\
6-8 \\
8-12 \\
12-\end{array}$ & $\begin{array}{c}3 \cdot 98 \\
7 \cdot 1 \\
9 \cdot 25 \\
17 \cdot 4\end{array}$ & $\begin{array}{c}9 \cdot 34 \\
13 \cdot 0 \\
13 \cdot 4 \\
20 \cdot 1\end{array}$ & $\begin{array}{l}6 \cdot 66 \\
10 \cdot 5 \\
11 \cdot 32 \\
18 \cdot 7\end{array}$ & $\begin{array}{l}26 \cdot 9 \\
16 \cdot 64 \\
8 \cdot 96 \\
3 \cdot 1\end{array}$ \\
\hline & $\begin{array}{l}20 \text { June } \\
\text { to } \\
21 \text { Aug. }\end{array}$ & $\begin{array}{l}0-8 \\
8-13 \\
13-17 \\
17-\end{array}$ & $\begin{array}{r}5 \cdot 4 \\
10 \cdot 8 \\
15 \cdot 1 \\
20 \cdot 3\end{array}$ & $\begin{array}{l}10 \cdot 43 \\
15 \cdot 6 \\
19 \cdot 8 \\
25 \cdot 5\end{array}$ & $\begin{array}{l}7 \cdot 91 \\
13 \cdot 2 \\
17 \cdot 45 \\
22 \cdot 9\end{array}$ & $\begin{array}{c}15 \cdot 0 \\
7 \cdot 18 \\
5 \cdot 02 \\
4 \cdot 13\end{array}$ \\
\hline & $\begin{array}{c}21 \text { Aug. } \\
\text { to } \\
2 \text { Nov. }\end{array}$ & $\begin{array}{c}0-4 \\
4-6 \\
6-16 \\
16-\end{array}$ & $\begin{array}{c}2 \cdot 86 \\
5 \cdot 28 \\
10 \cdot 9 \\
21 \cdot 1\end{array}$ & $\begin{array}{c}4 \cdot 9 \\
8 \cdot 24 \\
14 \cdot 0 \\
23 \cdot 6\end{array}$ & $\begin{array}{r}3 \cdot 33 \\
6 \cdot 76 \\
12 \cdot 45 \\
22 \cdot 35\end{array}$ & $\begin{array}{l}9 \cdot 8 \\
7 \cdot 68 \\
3 \cdot 89 \\
1 \cdot 62\end{array}$ \\
\hline & $\begin{array}{c}2 \text { Nov. } \\
\text { to } \\
7 \text { Dec. }\end{array}$ & $\begin{array}{l}0-6 \\
6-10 \\
10-20 \\
20-\end{array}$ & $\begin{array}{c}4 \cdot 47 \\
8 \cdot 66 \\
14 \cdot 2 \\
25 \cdot 6\end{array}$ & $\begin{array}{c}5 \cdot 07 \\
9 \cdot 05 \\
14 \cdot 5 \\
25 \cdot 9\end{array}$ & $\begin{array}{r}4 \cdot 77 \\
8 \cdot 55 \\
14 \cdot 35 \\
25 \cdot 75\end{array}$ & $\begin{array}{l}3 \cdot 83 \\
1 \cdot 28 \\
0 \cdot 61 \\
0 \cdot 33\end{array}$ \\
\hline 1932 & $\begin{array}{l}7 \text { Dec. } \\
\text { to } \\
12 \text { Jan. }\end{array}$ & $\begin{array}{l}0-7 \\
7-10 \\
10-15 \\
15-\end{array}$ & $\begin{array}{r}5 \cdot 27 \\
8 \cdot 85 \\
12 \cdot 07 \\
21 \cdot 0\end{array}$ & $\begin{array}{l}6 \cdot 24 \\
10 \cdot 13 \\
13 \cdot 29 \\
22 \cdot 6\end{array}$ & $\begin{array}{c}5 \cdot 75 \\
9 \cdot 49 \\
12 \cdot 68 \\
21 \cdot 8\end{array}$ & $\begin{array}{l}5 \cdot 12 \\
4 \cdot 03 \\
2 \cdot 81 \\
2 \cdot 11\end{array}$ \\
\hline & $\begin{array}{l}12 \text { Jan. } \\
\text { to } \\
9 \text { March }\end{array}$ & $\begin{array}{l}0-7 \\
7-15 \\
15-\end{array}$ & $\begin{array}{r}4 \cdot 64 \\
10 \cdot 24 \\
22 \cdot 63\end{array}$ & $\begin{array}{r}4 \cdot 94 \\
10 \cdot 36 \\
22 \cdot 73\end{array}$ & $\begin{array}{r}4 \cdot 79 \\
10 \cdot 30 \\
22 \cdot 68\end{array}$ & $\begin{array}{l}1 \cdot 38 \\
0 \cdot 25 \\
0 \cdot 09\end{array}$ \\
\hline & $\begin{array}{c}9 \text { March } \\
\text { to } \\
3 \text { May }\end{array}$ & $\begin{array}{l}0-5 \\
5-7 \\
7-10 \\
10-\end{array}$ & $\begin{array}{r}3 \cdot 94 \\
5 \cdot 89 \\
8 \cdot 85 \\
12 \cdot 77\end{array}$ & $\begin{array}{r}5 \cdot 84 \\
7 \cdot 73 \\
10 \cdot 50 \\
14 \cdot 30\end{array}$ & $\begin{array}{r}4 \cdot 89 \\
6 \cdot 81 \\
9 \cdot 67 \\
13 \cdot 53\end{array}$ & $\begin{array}{l}8 \cdot 61 \\
5 \cdot 70 \\
4 \cdot 02 \\
2 \cdot 18\end{array}$ \\
\hline
\end{tabular}


TABLE II.

The Growth Rates on the B. 2 Patch throughout the Year.

Volumes in cubic millimetres.

\begin{tabular}{|c|c|c|c|c|c|c|}
\hline & Date. & $\begin{array}{c}\text { Initial } \\
\text { volume } \\
\text { range. }\end{array}$ & $\begin{array}{c}\text { Initial } \\
\text { volume } \\
\text { average. }\end{array}$ & $\begin{array}{c}\text { Final } \\
\text { volume } \\
\text { average. }\end{array}$ & $\begin{array}{l}\text { Mean } \\
\text { volume } \\
\text { for the } \\
\text { period. }\end{array}$ & $\begin{array}{c}\text { Growth } \\
\text { rate. }\end{array}$ \\
\hline 1931 & $\begin{array}{l}12 \text { Jan. } \\
\text { to } \\
25 \text { April }\end{array}$ & $\begin{array}{c}0-4 \\
4-8 \\
8-15 \\
15-25 \\
25-\end{array}$ & $\begin{array}{c}3 \cdot 1 \\
5 \cdot 65 \\
10 \cdot 6 \\
19 \cdot 4 \\
36 \cdot 6\end{array}$ & $\begin{array}{l}8 \cdot 3 \\
12 \cdot 55 \\
16 \cdot 8 \\
25 \cdot 4 \\
44 \cdot 3\end{array}$ & $\begin{array}{c}5 \cdot 6 \\
9 \cdot 1 \\
15 \cdot 7 \\
22 \cdot 4 \\
40 \cdot 35\end{array}$ & $\begin{array}{c}15 \cdot 75 \\
11 \cdot 85 \\
5 \cdot 68 \\
3 \cdot 0 \\
2 \cdot 20\end{array}$ \\
\hline & $\begin{array}{l}25 \text { April } \\
\text { to } \\
20 \text { June }\end{array}$ & $\begin{array}{c}0-7 \\
7-10 \\
10-15 \\
15-20 \\
20-30\end{array}$ & $\begin{array}{r}5 \cdot 6 \\
8 \cdot 5 \\
11 \cdot 7 \\
17 \cdot 4 \\
24 \cdot 0\end{array}$ & $\begin{array}{l}11 \cdot 9 \\
14 \cdot 0 \\
16 \cdot 1 \\
22 \cdot 5 \\
30 \cdot 6\end{array}$ & $\begin{array}{l}8 \cdot 75 \\
11 \cdot 25 \\
13 \cdot 9 \\
19 \cdot 95 \\
27 \cdot 3\end{array}$ & $\begin{array}{c}20 \cdot 1 \\
11 \cdot 5 \\
6 \cdot 72 \\
5 \cdot 06 \\
4.92\end{array}$ \\
\hline & $\begin{array}{l}20 \text { June } \\
\text { to } \\
21 \mathrm{Aug} .\end{array}$ & $\begin{array}{l}0-12 \\
12-15 \\
15-20 \\
20-\end{array}$ & $\begin{array}{r}9 \cdot 6 \\
13 \cdot 3 \\
17 \cdot 6 \\
31 \cdot 4\end{array}$ & $\begin{array}{l}14 \cdot 2 \\
17 \cdot 8 \\
22 \cdot 5 \\
39 \cdot 4\end{array}$ & $\begin{array}{l}12 \cdot 9 \\
15 \cdot 55 \\
20 \cdot 05 \\
35 \cdot 4\end{array}$ & $\begin{array}{l}7 \cdot 75 \\
5 \cdot 45 \\
4 \cdot 26 \\
4 \cdot 10\end{array}$ \\
\hline & $\begin{array}{l}21 \text { Aug. } \\
\text { to } \\
16 \text { Oct. }\end{array}$ & $\begin{array}{c}0-7 \\
7-10 \\
10-13 \\
13-19 \\
19-30 \\
30-\end{array}$ & $\begin{array}{r}5 \cdot 1 \\
8 \cdot 6 \\
11 \cdot 4 \\
15 \cdot 9 \\
24 \cdot 4 \\
38 \cdot 9\end{array}$ & $\begin{array}{r}8 \cdot 3 \\
11 \cdot 3 \\
14 \cdot 9 \\
19 \cdot 5 \\
29 \cdot 6 \\
46 \cdot 2\end{array}$ & $\begin{array}{l}6 \cdot 7 \\
9 \cdot 95 \\
13 \cdot 15 \\
17 \cdot 7 \\
27 \cdot 0 \\
42 \cdot 55\end{array}$ & $\begin{array}{c}11 \cdot 2 \\
5 \cdot 62 \\
5 \cdot 49 \\
4 \cdot 5 \\
3 \cdot 81 \\
3 \cdot 34\end{array}$ \\
\hline 1932 & $\begin{array}{l}16 \text { Oct. } \\
\text { to } \\
14 \text { Jan. }\end{array}$ & $\begin{array}{l}0-10 \\
10-15 \\
15-20 \\
20-\end{array}$ & $\begin{array}{l}7 \cdot 12 \\
12 \cdot 60 \\
17 \cdot 40 \\
32 \cdot 4\end{array}$ & $\begin{array}{l}8 \cdot 57 \\
13 \cdot 87 \\
18 \cdot 50 \\
33 \cdot 8\end{array}$ & $\begin{array}{l}7 \cdot 84 \\
13 \cdot 23 \\
17 \cdot 95 \\
33 \cdot 1\end{array}$ & $\begin{array}{l}2 \cdot 27 \\
1 \cdot 12 \\
0 \cdot 70 \\
0 \cdot 48\end{array}$ \\
\hline
\end{tabular}


TABLE III.

The Growth Rates on the B. 3 Patch throughout the Year.

Volumes in cubic millimetres.

Date.

1931

13 Jan.
to
29 April

29 April

13 June

13 June

to

18 Aug.

18 Aug.

19 Oct.

9 Oct.

9 Dec.

9.ec.

9 Dec.

1932

14 Jan.

Initial
volume

range.

$\begin{array}{cc}\begin{array}{c}\text { Initial } \\ \text { volume } \\ \text { range. }\end{array} & \begin{array}{c}\text { Initial } \\ \text { volume } \\ \text { average. }\end{array} \\ 0-6 & 4 \cdot 2 \\ 6-10 & 8 \cdot 01 \\ 10-30 & 21 \cdot 9 \\ 30-40 & 34 \cdot 7 \\ 40-70 & 57 \cdot 1 \\ 70- & 129 \cdot 0\end{array}$

Final

volume

average.

Mean

volume

for the

period.

Growth

$8 \cdot 8$

$13 \cdot 25$

$32 \cdot 0$

$47 \cdot 0$

$68 \cdot 25$

$142 \cdot 0$

$6 \cdot 5$

$10 \cdot 7$

$26 \cdot 95$

$40 \cdot 85$

$62 \cdot 6$

$135 \cdot 5$

rate.

$\begin{array}{rr}0-18 & 11 \cdot 3 \\ 18-40 & 22 \cdot 3 \\ 35-50 & 43 \cdot 1 \\ 45-55 & 51 \cdot 0 \\ 55-75 & 63 \cdot 2 \\ 75- & 124 \cdot 5\end{array}$

$16 \cdot 4$

$29 \cdot 7$

$48 \cdot 1$

$54 \cdot 0$

$66 \cdot 2$

$132 \cdot 5$

\section{$13 \cdot 8$}

$26 \cdot 0$

$45 \cdot 6$

$52 \cdot 5$

$64 \cdot 7$

$128 \cdot 5$

$10 \cdot 4$

$6 \cdot 22$

$3 \cdot 91$

$3 \cdot 35$

$1 \cdot 86$

$0 \cdot 95$

$$
\text { 0-20 }
$$

20-30

30-40

40-70

$15 \cdot 0$

$23 \cdot 2$

$34 \cdot 7$

$70-$

$53 \cdot 45$

$26 \cdot 2$

31.9

$44 \cdot 1$

$63 \cdot 32$

\section{$20 \cdot 6$}

$27 \cdot 55$

$39 \cdot 4$

$57 \cdot 88$

$10 \cdot 0$

$7 \cdot 4$

$2 \cdot 6$

1.74

$1 \cdot 41$

$1 \cdot 43$

\section{0-5}

$$
\text { 5-15 }
$$

$147 \cdot 2$

$154 \cdot 6$

$150 \cdot 9$

$11 \cdot 3$

$5 \cdot 68$

$4 \cdot 12$

$2 \cdot 51$

$0 \cdot 76$

8.44

$5 \cdot 44$
$10 \cdot 82$

$4 \cdot 7$

$5 \cdot 28$

15-30

$21 \cdot 9$

$10 \cdot 82$

$30-45$

$38 \cdot 0$

$24 \cdot 7$

$41 \cdot 5$

$52 \cdot 8$

$63 \cdot 6$

55-65 $\quad 60 \cdot 6$

65-80 $\quad 70 \cdot 9$

80 -

$126 \cdot 0$

$73 \cdot 6$

$129 \cdot 6$

$23 \cdot 3$

$39 \cdot 75$

$5 \mathrm{I} \cdot 6$

$62 \cdot 1$

$72 \cdot 75$

$127 \cdot 8$

$4 \cdot 55$

$2 \cdot 60$

$1 \cdot 49$

$0 \cdot 77$

$0 \cdot 80$

$0 \cdot 62$

$0 \cdot 46$

$\begin{array}{rlrll}0-10 & 6 \cdot 15 & 8 \cdot 15 & 7 \cdot 15 & 5 \cdot 35 \\ 3-15 & 10 \cdot 35 & 11 \cdot 72 & 11 \cdot 03 & 2 \cdot 27 \\ 10-50 & 31 \cdot 8 & 33 \cdot 8 & 32 \cdot 8 & 1 \cdot 0 \\ 50- & 97 \cdot 1 & 101 \cdot 5 & 99 \cdot 3 & 0 \cdot 74\end{array}$

\section{0-10}

$10-30$

$7 \cdot 09$

$19 \cdot 05$

$30-50 \quad 38 \cdot 91$

$\begin{array}{ll}50-70 & 58 \cdot 7\end{array}$

$10 \cdot 07$

8.58

8.58
20.97

$11 \cdot 65$

$22 \cdot 90$

$43 \cdot 16$

$63 \cdot 2$

$41 \cdot 03$

$60 \cdot 95$

$5 \cdot 62$

$3 \cdot 04$

$94 \cdot 1$

$100 \cdot 64$

$97 \cdot 87$ 


\section{TABLE IV.}

Relation of Year's mean Growth Rate to Size at the three Stations.

Volumes in cu. mm.

\begin{tabular}{cc|cc|cc}
\multicolumn{2}{c|}{ B. 1 } & \multicolumn{2}{|c|}{ B. 2} & \multicolumn{2}{c}{ B. 3} \\
Volume. & $\begin{array}{c}\text { Growth } \\
\text { rate. }\end{array}$ & Volume. & $\begin{array}{c}\text { Growth } \\
\text { rate. }\end{array}$ & Volume. & Growth \\
7 & $9 \cdot 95$ & 10 & $8 \cdot 08$ & $17 \cdot 5$ & $6 \cdot 59$ \\
10 & $5 \cdot 94$ & 12 & $6 \cdot 10$ & 20 & $5 \cdot 85$ \\
13 & $3 \cdot 84$ & 15 & $4 \cdot 32$ & 25 & $3 \cdot 12$ \\
16 & $3 \cdot 25$ & 17 & $3 \cdot 74$ & 35 & $2 \cdot 04$ \\
19 & $2 \cdot 09$ & 20 & $3 \cdot 27$ & 50 & $1 \cdot 41$ \\
22 & $1 \cdot 70$ & 30 & $2 \cdot 86$ & 75 & $1 \cdot 19$ \\
& & 40 & $2 \cdot 71$ & 100 & $1 \cdot 05$
\end{tabular}

TABLE V.

Volumes (In CU. Mm.) of Young Individuals in their fiRst Year.

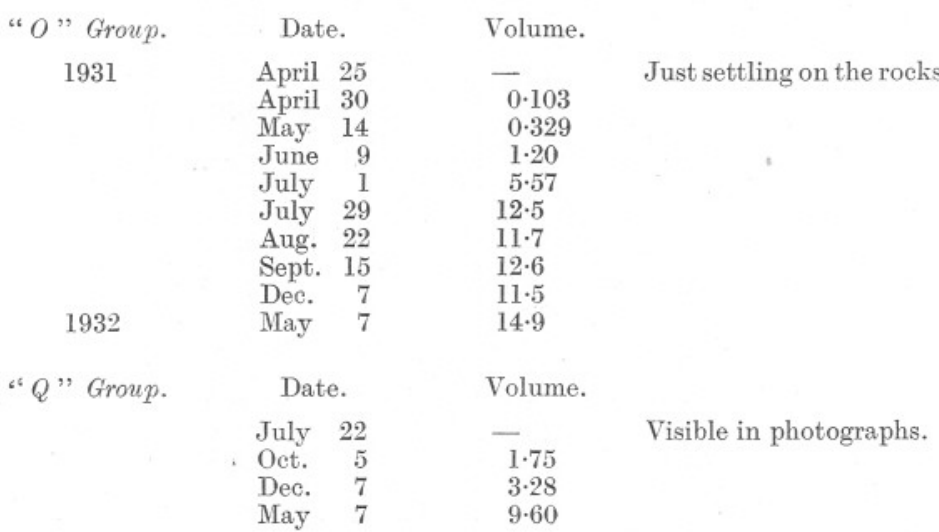




\section{TABLE VI.}

Calculated Growth throughout the Life of a typical Member of B. 1 Patch, as deduced from CuRves dRAWn from Table I ; the inttial Volume, on August 21, 1931, Being 4.66 cu. ma.

\section{Period.}

1st year

3rd year

2nd year

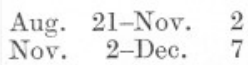

Dec. 7-Jan. 12

Jan. 12-March 9

March 9-May 1

May 1-June 20

June 20-Aug. 21

Aug. 21-Nov. 2

Nov. 2-Dec. 7

Dec. 7-Jan. 12

Jan. 12-March 9

March 9-May 1

May 1-June 20

June 20-Aug. 21

Aug. 21-
Volume at

commencement Growth rate of period. during period.

$\begin{array}{rl}4 \cdot 66 & 8 \cdot 00 \\ 7 \cdot 38 & 1 \cdot 68 \\ 7 \cdot 82 & 4 \cdot 18 \\ 9 \cdot 00 & 0 \cdot 30 \\ 9 \cdot 13 & 3 \cdot 58 \\ 10 \cdot 93 & 7 \cdot 26 \\ 14 \cdot 89 & 5 \cdot 10 \\ 19 \cdot 60 & 1 \cdot 80 \\ 22 \cdot 17 & 0 \cdot 37 \\ 22 \cdot 46 & 2 \cdot 06 \\ & \\ 24 \cdot 13 & 0 \cdot 08 \\ 24 \cdot 22 & 0 \cdot 84 \\ 25 \cdot 34 & 1 \cdot 53 \\ 27 \cdot 28 & 3 \cdot 99 \\ 33.53 & \end{array}$

\section{TABLE VII.}

Calculated Growth throughout the Life of a typical Member of B. 2 Patch, as deduced from Curves drawn from Table II ; the initial Volume, on August 21, 1931, Being 8.84 cu. my.

1st year

2nd year

3rd year
Period.

Volume at

commencement Growth rate of period. during period.

Aug. 21-Oct. 16

Oct. 16-Jan. 12

Jan. 12-April 25

April 25-June 20

June 20-Aug. 21

Aug. 21-Oet. 16

Oct. 16-Jan. 12

Jan. 12-April 25

April 25-June 20

June 20

$\begin{array}{rr}8 \cdot 84 & 5 \cdot 74 \\ 11 \cdot 68 & 1 \cdot 11 \\ & \\ 12 \cdot 85 & 4 \cdot 46 \\ 18 \cdot 75 & 4 \cdot 98 \\ 23 \cdot 99 & 4 \cdot 10 \\ 30 \cdot 09 & 3 \cdot 56 \\ 36 \cdot 09 & 0 \cdot 49 \\ & \\ 37 \cdot 68 & 2 \cdot 16 \\ 46 \cdot 08 & 4 \cdot 92\end{array}$

$58 \cdot 73$ 


\section{TABLE VIII.}

Calculated Growth throughout the Life of a typical Member of B. 3 Patch as deduced from Curves drawn from Table III ; the initial Volume, on August 18, 1931, Being 6 38 CU. ma.

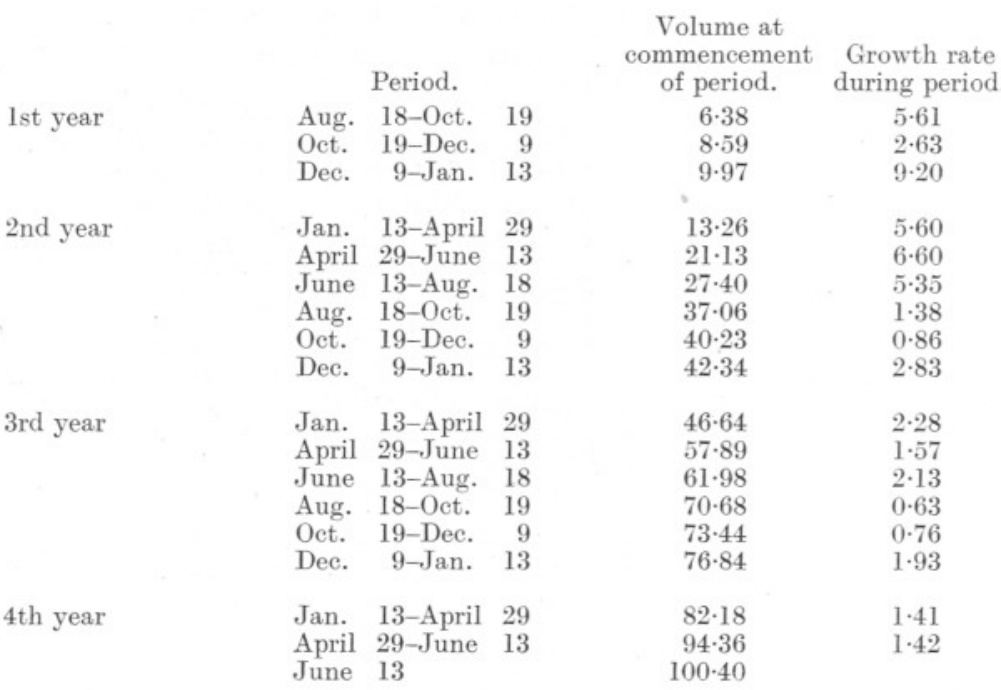

\section{TABLE IX.}

Size Distribution (Lengths, in mm.) on the three Patches on June 2, 1932. Lengths measured to the nearest whole ma. The 1932 Spat, shown in Brackets in the numbers Column, are excluded in the Calculation of the Percentages.

\begin{tabular}{|c|c|c|c|c|c|c|}
\hline & \multicolumn{2}{|c|}{ B. 1} & \multicolumn{2}{|c|}{ B. 2} & \multicolumn{2}{|c|}{ B. 3} \\
\hline Length. & No. & $\%$ & No. & $\%$ & No. & $\%$ \\
\hline 1 & - & - & - & - & - & - \\
\hline 2 & $(597)$ & - & (559) & - & $(437)$ & - \\
\hline & - & - & - & - & 1 & $0 \cdot 33$ \\
\hline 4 & 44 & $13 \cdot 4$ & 4 & $1 \cdot 22$ & 3 & $0 \cdot 99$ \\
\hline 5 & 102 & $31 \cdot 1$ & 20 & $6 \cdot 14$ & 8 & $2 \cdot 64$ \\
\hline 6 & 108 & $32 \cdot 9$ & 39 & $11 \cdot 9$ & 24 & $7 \cdot 94$ \\
\hline 7 & 64 & $19 \cdot 4$ & 81 & $24 \cdot 8$ & 47 & $15 \cdot 5$ \\
\hline 8 & 8 & $2 \cdot 43$ & 65 & $19 \cdot 8$ & 48 & $15 \cdot 8$ \\
\hline 9 & 2 & $0 \cdot 61$ & 52 & $15 \cdot 9$ & 64 & $21 \cdot 1$ \\
\hline 10 & - & $0 \cdot 0$ & 45 & $13 \cdot 8$ & 49 & $16 \cdot 1$ \\
\hline 11 & 1 & $0 \cdot 33$ & 13 & $3 \cdot 98$ & 29 & $9 \cdot 60$ \\
\hline 12 & - & $0 \cdot 0$ & 7 & $2 \cdot 14$ & 13 & $4 \cdot 30$ \\
\hline 13 & - & - & 1 & $0 \cdot 31$ & 9 & $2 \cdot 97$ \\
\hline 14 & - & - & - & - & 5 & $1 \cdot 65$ \\
\hline 15 & - & - & - & - & 3 & 0.99 \\
\hline 16 & - & - & - & - & - & - \\
\hline Total & $\begin{array}{c}329 \\
(597)\end{array}$ & & $\begin{array}{r}327 \\
(559)\end{array}$ & & $\begin{array}{c}303 \\
-(437)\end{array}$ & \\
\hline
\end{tabular}

